December 2014

\title{
Social, Legal, and Technical Issues in the Library
}

Adrienne Mathewson

desertrhythm@gmail.com

Follow this and additional works at: https://scholarworks.sjsu.edu/ischoolsrj

Part of the Information Literacy Commons, Scholarly Communication Commons, and the Scholarly Publishing Commons

\section{Recommended Citation}

Mathewson, A. (2014). Social, Legal, and Technical Issues in the Library. School of Information Student Research Journal, 4(2). https://doi.org/10.31979/2575-2499.040201 Retrieved from https://scholarworks.sjsu.edu/ischoolsrj/vol4/iss2/1

This article is brought to you by the open access Journals at SJSU ScholarWorks. It has been accepted for inclusion in School of Information Student Research Journal by an authorized administrator of SJSU ScholarWorks. For more information, please contact scholarworks@sjsu.edu. 


\section{Social, Legal, and Technical Issues in the Library}

About Author

Adrienne Mathewson is Editor-in-Chief of SJSJ School of Information Student Research Journal. She resides in Albuquerque, New Mexico and works as a freelance writer and editor. 
I am proud to announce that the Editorial Team of the Student Research Journal (SRJ), published by the San José State University School of Information, has produced another excellent issue. Our second issue of Volume 4 includes an Invited Contribution by a retired New Mexico State Corrections librarian, and three articles from Library and Information Science (LIS) graduate students from SJSU's School of Information, and one from a LIS graduate student at SUNY Buffalo.

Under the guidance of Sara Kelso, SRJ's outstanding Managing Editor, our content and copy editors maintained the high quality of the journal through their careful and thoughtful evaluation of submissions. This issue was created through the efforts of our content editors - Alex Post, Alicia Zuniga, Laura Stanger, Lawrence Mak, Jason Baker, Tacoma Tomlinson along with Stephanie Routhier-Perry and Kristin Clark, our eagle-eyed copy editors.

Along with producing the journal, our team members presented at the Library 2.014 conference. The presenters discussed best practices for authors and editors of peer-reviewed publication and manuscript submission during their presentation of "Get Published! The Best Advice for Students Submitting to PeerReviewed Journals".

The articles published in this issue point out how modern librarians use a multi-disciplinary approach to serving their patron base. For some librarians, such as our invited contributor, a former prison librarian, going to work each day means facing safety and security issues in a stressful prison environment. Public librarians face security issues, as well, as many of the homeless population use their facilities on a daily basis. Along with the social aspects of their jobs, librarians must familiarize themselves with several legal issues, such as website filtering, copyright laws, First Amendment and technical issues.

Vince Wiggins, a retired New Mexico Corrections librarian, provides the reader with an account of the day in the life of a prison librarian in his article "A Correctional Type of Day". Librarians in prisons face many challenges, but as Wiggins says, "while it's not everybody's dream job, it can be rewarding". He explains that many times inmates simply need somebody to talk to and "listening can help prevent fights, stabbings, bullying... or other types of disturbances".

Paul Kiaidy Barrows defines the social aspect of librarianship further in his article "Serving the Needs of Homeless Library Patrons: Legal Issues, Ethical Concerns, and Practical Approaches". According to Barrows, libraries have a commitment to "democracy and equal access" but providing services to homeless populations may test that commitment. As well, homeless people have a range of information needs and libraries provide their primary access to information.

Another social and legal issue facing librarians, particularly in school settings, is that of website filtering. Jennifer Overaa discusses the Children's Internet Protection Act (CIPA), a federal law that "requires public schools and 
libraries to use filters as a condition of receiving federal funding for technology". Her article provides a legal background of CIPA and discusses the impact such filtering has on students' education in terms of the digital divide, lost opportunities for online education, and loss of educators' control.

Amanda MCormick provides an excellent review of literature on copyright in her article "Copyright, Fair Use and the Digital Age in Academic Libraries: A Review of the Literature". Research indicates that "librarians must play an increased role in copyright law education" as librarians are "stewards of information... (and) the library is the main access point through which information flows".

Julee Tanner, in her paper on the future of the book, explains that restrictive publisher licenses and high costs limit the amount of digital books available for checkout from public libraries. The article "Digital vs. Print: Reading Comprehension and the Future of the Book" provides a fascinating explanation on the "advantages of reading from printed books, e-readers, and computer displays from the perspectives of the optical issues, cognitive needs, and metacognitive habits of different readers".

Every day, librarians face myriad issues as they grapple with the social and legal needs of their patrons while dealing with ever-changing technology. Librarians must educate themselves continually as they provide solutions to people from every walk of life. Research journals such as $S R J$, help librarians keep up with the latest research so they can continue to provide services to diverse populations. We thank you, our readers, for your continued interest in our articles, and we thank our contributors who work so hard to advance LIS scholarly research.

I'd like to give a very special thanks to Sara Kelso who always went over and beyond her duties as Managing Editor, I greatly appreciate all her hard work and devotion to the journal. Also, a very special note of appreciation to our faculty advisor, Dr. Anthony Bernier who continues his dedication and support to $S R J$, along with the Editorial Board members and School of Information faculty members. 